\title{
PENGARUH PENGAWASAN TERHADAP KINERJA PEGAWAI PADA KANTOR DINAS PERINDUSTRIAN DAN PERDAGANGAN PROVINSI RIAU
}

\author{
Hendrayani \\ Sekolah Tinggi Ilmu Ekonomi Riau \\ E-mail: hendrayani@lecturer.stieriau-akbar.ac.id
}

\begin{abstract}
The research was conducted at Department of Industry and Trade of Riau Province. Based on the background of the research mentioned above, the authors can formulate the problem in this study is whether the Supervision significantly influence the Performance of Employees at the Office of Industry and Trade of Riau Province. The purpose of this study is to determine the effect of supervision on the performance of employees of the Office of Industry and Trade of Riau Province ..Data analysis in this research is done by using descriptive and quantitative method. Descriptive method of data analysis by decomposition of theories contained in the bibliography and associated with the data obtained from the results of research that will be collected, grouped and tabulated then taken conclusions. And the quantitative method with linear regression technique sedrhana .. The sample taken in this research is amounted to 69 people, Based on the above output obtained t-count value of 9.626 while for the value t_tabel obtained the value of t_hitung (9,626)> from t_tabel (1.99601), so it can be concluded that there is a significant effect of supervision on employee performance, obtained the value of $R_{-}$square or coefficient of determination of 0.580, which has the meaning of the influence of supervisory variables against the kiner ja of $58.0 \%$ while the rest of $42.0 \%$ describe other independent variables that are not observed in this study.
\end{abstract}

Keywords: Pengawasan dan Kinerja

\section{A. PENDAHULUAN}

Suatu organisasi atau lembaga harus mampu mengelola sumber daya dimilikinya, termasuk sumber daya manusia. Karena sumber daya manusia merupakan asset utama yang besar pengaruhnya terhadap kemajuan organisasi. Seperti yang diketahui selama ini, organisasi lebih banyak menghadapi masalah-masalah yang berhubungan dengan sumber daya manusia apabila dibandingkan dengan sumber daya ekonomi lainnya, karena dalam mengelola sumber daya manusia tidak bisa disamakan dengan mesin, material dan yang sifatnya hanya masalah teknis saja. Hal ini menjadi suatu masalah yang cukup rumit, sehingga organisasi mengalami kesulitan dalam menentapkan kebijakan terutama yang berhubungan dengan sumber daya manusia.

Peranan sumber daya manusia merupakan salah satu faktor utama yang sangat penting dalam organisasi. Pemanfaatan sumber daya manusia secara efektif merupakan jalan bagi suatu organisasi untuk mempertahankan kelangsungan hidup dan pertumbuhan dimasa yang akan datang. Dengan kata lain, keberhasilan atau kemunduran suatu organisasi tergantung pada keahlian dan keterampilan pegawainya masing-masing yang bekerja didalamnya.

Untuk menciptakan keberhasilan kerja seorang pegawai, seorang pemimpin harus melakukan suatu langkah manajemen agar tujuan organisasi dapat tercapai. Salah satu langkah tersebut adalah melakukan pengawasan terhadap segala sesuatu pekerjaan yang dilakukan seorang pegawai. Pengawasan menjadi suatu unsur yang terpenting dalam pembinaan individu didalam organisasi, karena pengawasan merupakan tenaga penggerak bagi para bawahan atau karyawan agar dapat bertindak sesuai dengan apa yang telah direncanakan menurut aturan yang berlaku.

Upaya dalam mewujudkan hal itu, maka dapat menciptakan kondisi dan iklim kerja yang mendukung serta menciptakan pengawasan sebagai suatu proses yang wajar dalam suatu organisasi pemerintah dilakukan pengawasan secara maksimal maka akan mendorong pelaksanaan tugas pegawai dan kinerja pegawai dalam pencapaian tujuan yang diharapkan.

Peningkatan kinerja pegawai dibutuhkan kemampuan dari pucuk pimpinan untuk memperhatikan kecakapan hubungan antar staf/pegawai dalam 
melaksanakan pengawasan yang mana merupakan seluruh segenap aktifitas mengawasi, mmeriksa, mencocokkan, mengendalikan segenap kegiatan pegawai yang tentunya akanmengarah kepada pembinaan para pegawai, sehingga pegawai dapat pula memahami tugas dan tanggung jawab masing-masing serta mematuhi atranaturan yang telah ditetapka sebelumnya dan demikian tentunya akan berpengaruh pada peningkatan kinerja pegawai. Sehubungan dengan sifat dari pekerjaan serta keadaan yang selalu dinamis dan selalu berkembang sebagai akibat tuntutan pelaksanaan pembangunan agar berjalan tertib dan lancer maka diperlukan pegawai yang benar-benar cakap, terampil dan tanggug dalam melaksanakan tugas dan pekerjaannya. Sumber Daya Manusia menempati poisi strategis dalam pembangunan daerah dan pembangunan sumber daya manusia merupakan kunci keberhasilan bagi segenap bidang pembangunan yang diselenggarakan di daerah. Hal ini mengandung pengertian bahwa kinerja pegawai merupakan sarana penentu dalam mencapai tujuan organisasi pemerintahan. Pembinaan mutu penyelenggara pemerintah daerah perlu dilaksanakan terus menerus dan berkesinambungan sehingga Sumber daya anusia yang terlibat dalam proses tersebut mampu menjawab tantangan pembangunan daerah serta dapat memperbaiki kinerja Sumber Daya Manusia yang selama ini rendah.

Untuk mendapatkan hasil yang lebih baik, maka pengawasan harus dilakukan secara berkelanjutan sesuai keutuhan untuk menyelesaikan tugas dan pekerjan karyawan atau pegawai sesuaidengan rencan yang ditetapkan dan dikehendaki oleh pengawas yaitu pimpinan.

Pengawasan merupakan hal penting disetiap pekerjaan dalam perusahaan atau instansi pemerintah, dikarenakan dengan adanya pengawasan yang baik, maka suatu pekerjaan akan berjalan dengan lancer an menghasilkan kerjaan yang optimal Bila pekerjaan dibarengi dengan pengawasan pasti hasilnya akan sangat baik dan

Eko dan Bisnis (Riau Economics and Business Reviewe) Volume 10, Nomor 4, 27 Desember 2019 memuaskan. Hal ini mengandung pengertian bahwa kinerja pegawai merupakan sarana penentu dalam mencapai tujuan organisasi pemerintahan. J.B. Sumarlin (2004) menyatakan bahwa dengan semakin besarnya tuntutan masyarakat terhadap penyelenggaraan pemerintahan negara yang didasarkan pada prinsip-prinsip governance, maka keutuhan terhadap peran pengawasan akan semakin meningkat. Pengawasan perlu dilaksanakan secara optimal yaitu dilaksanakan secara efektif dan efisien serta bermanfaat bagi audit (organisasi, pemerintah dan negara) dalam merealiasasikan tujuan/program secara efektif, efisien dan ekonomis baik itu dalam lingkup kantor Dinas Perindustrian dan Perdagangan Provinsi Riau. Dimana sering ditemukan pegawai tak berada dikantor di saat jam kerja dan kurang efektif dan efisien dalam bekerja. Dan pengawasan menjadi salah satu factor yang menentukan kinerja pegawai agar lebih baik.

Pengawasan yang dilaksanakan bukan ditujukan untuk mencari-cari kesalahan atau mencari siapa yang salah, melainkan untuk memahami apa yang salah dan mengoptimalkan pencapaian tujuan yang telah ditetapkan serta mencegah terjadinya penyimpangan dan penyelewengan dari rencana yang telah ditentukan semula.

Jumlah Pegawai Dinas Perindustrian dan Perdagangan Provinsi Riau sudah mencukupi sesuai dengan jumlah Bidang yang ada.

Tabel 1. Laporan Rekapitulasi Absensi (Ketidakhadiran) Pegawai Dinas Perindustrian dan Perdagangan Provins Riau selama 5 Tahun terakhir

\begin{tabular}{|c|c|c|c|c|c|}
\hline Tahun & $\begin{array}{c}\text { Jumlah } \\
\text { Pegawai }\end{array}$ & $\begin{array}{c}\text { Hari Kerja } \\
\text { Efektif }\end{array}$ & $\begin{array}{c}\text { Jumlah total } \\
\text { hari kerja }\end{array}$ & Alpa & $\begin{array}{c}\text { \% } \\
\text { Kehadiran }\end{array}$ \\
\hline 2013 & 229 & 249 & 57.021 & 54 & 99.94 \\
\hline 2014 & 227 & 244 & 55.388 & 45 & 99.82 \\
\hline 2015 & 209 & 253 & 52.877 & 41 & 99.92 \\
\hline 2016 & 220 & 248 & 54.120 & 35 & 99.93 \\
\hline 2017 & 223 & 246 & 52.398 & 42 & 99.92 \\
\hline
\end{tabular}

Sumber : Data Dinas Perindustrian dan Perdagangan Provinsi Riau, 2018

Berdasarkan tabel di atas jumlah tingkat kehadiran Pegawai Dinas Perindustrian dan Perdagangan Provinsi P.ISSN: 1410-7988 E.ISSN: 2614-123X 
Riau pada tahun 2013 sebesar 99.94\%, 2014 sebesar $99.82 \%$, tahun 2015 sebesar $99.92 \%$, tahun 2016 sebesar $99.93 \%$ dan tahun 2017 sebesar $99.92 \%$, sehingga dilhat dari data diatas masih ada pegawai yang tidak masuk, maka perlu binaan dan aturan sehingga jika ada pegawai yang tidak mengikuti peraturan tersebut maka akan diberikan sanksi.

\section{Tabel 2. Rekapitulasi Capaian Anggaran}

\begin{tabular}{|l|l|l|c|}
\hline \multirow{2}{*}{ Tahun } & \multicolumn{3}{|c|}{ Anggaran } \\
\cline { 2 - 4 } & \multicolumn{1}{|c|}{ Rencana } & \multicolumn{1}{|c|}{ Realisasi } & \% Capaian \\
\hline 2013 & Rp. 10.267 .793 .600 & Rp. 7.495 .301 .567 & $73,00 \%$ \\
\hline 2014 & Rp. 43.006 .385 .912 & Rp. 22.306 .108 .574 & $51,87 \%$ \\
\hline 2015 & Rp. 44.390 .041 .230 & Rp. 32.686 .357 .796 & $73,63 \%$ \\
\hline 2016 & Rp. 6.246 .536 .266 & Rp. 5.197 .051 .556 & $83,20 \%$ \\
\hline 2017 & Rp. 39.525.524.332 & Rp. 27.516 .351 .333 & $69,62 \%$ \\
\hline
\end{tabular}

Sumber : Data Dinas Perindustrian dan Perdagangan Provinsi Riau, 2018

Tabel 3 Rekapitulasi target dan realisasi Kegiatan

\begin{tabular}{|c|c|c|c|}
\hline \multirow{2}{*}{ Tahun } & \multicolumn{3}{|c|}{ Pelaksanaan Kegiatan } \\
\cline { 2 - 4 } & Target & Realisasi & $\%$ Capaian \\
\hline 2013 & $61 \mathrm{Keg}$ & $47 \mathrm{Keg}$ & $77,05 \%$ \\
\hline 2014 & $29 \mathrm{Keg}$ & $28 \mathrm{Keg}$ & $96,55 \%$ \\
\hline 2015 & $75 \mathrm{Keg}$ & $66 \mathrm{Keg}$ & $88,00 \%$ \\
\hline 2016 & $100 \mathrm{Keg}$ & $92 \mathrm{Keg}$ & $92,00 \%$ \\
\hline 2017 & $107 \mathrm{Keg}$ & $95 \mathrm{Keg}$ & $88,79 \%$ \\
\hline
\end{tabular}

Sumber : Data Dinas Perindustrian dan Perdagangan Provinsi Riau, 2018

Berdasarkan tabel 2 dan table 3 diatas dapat dijelaskan, bahwa selama 5 tahun dari tahun 2013 sampai dengan tahun 2017 pencapaian persentasi anggaran dalam penyelesaian realisasi kegiatan yang ada pada Dinas Perindustrian dan Perdagangan Provinsi Riau tidak pernah mencapai dengan 99\%. Disini dapat kita ketahui, kurangnya pengawasan dalam pengelolaan anggaran oleh pimpinan Dinas Perindustrian dan Perdagangan Provinsi Riau sehingga kinerja yang dihasilkan oleh pegawai Dinas Perindustrian dan Perdagangan Provinsi Riau tidak begitu optimal.

Dari latar belakang diatas, pengaruh pengawasan terhadap kinerja pegawai menjadi sangat penting untuk dibahas dan diteliti, hal ini bermaksud untuk melihat apakah dengan diadakannya pengawasan ini dapat berpenaruh terhadap kinerja pegawai.

\section{Manajemen Sumber Daya Manusia}

Berbagai istilah yang dipakai untuk menunjukkan manajemen sumber daya manusia antara lain: manajemen sumber daya

Eko dan Bisnis (Riau Economics and Business Reviewe) Volume 10, Nomor 4, 27 Desember 2019 manusia, manajemen sumber daya insani, manajemen personalia, manajemen kepegawaiaan, manajemen perburuhan, manajemen tenaga kerja, administrasi personalia (kepegawaian), dan hubungan industrial.

Manajemen sumber daya manusia timbul sebagai masalah baru pada tahun 1960-an, sebelum itu kurang lebih pada tahun 1940-an yang mendominasi adalah manajemen personalia. Antara keduanya jelas terdapat perbedaan di dalam ruang lingkup dan tingkatannya. Manajemen sumber daya manusia mencakup masalahmasalah yang berkaitan dengan pembinaan, penggunaan dan perlindungan sumber daya manusia; sedangkan manajemen personalia lebih banyak berkaitan dengan sumber daya manusia yang berada dalam perusahaanperusahaan, yang umum dikenal dengan sector modern itu. Tugas manajemen personalia adalah mempelajari dan mengembangkan cara-cara agar manusia dapat secara efektif di integrasikan ke dalam berbagai organisasi guna mencapai tujuannya, (Faustino; 2003:2).

Manajemen sumber daya manusia merupakan salah satu bidang dari manajemen umum yang meliputi segi-segi perencanaan, pengorganisasian, pelaksanaan dan pengendalian. Proses ini terdapat dalam fungsi atau bidang produksi, pemasaran, keuangan maupun kepegawaian. Karena sumber daya manusia dianggap semakin penting peranannya dalam pencapaian tujuan, maka berbagai pengalaman dan hasil penelitian dalam bidang sumber daya manusia (SDM) dikumpulkan secara sistematis dalam apa yang disebut dengan Manajemen sumber daya manusia. Istilah "manajemen" mempunyai arti sebagai kumpulan pengetahuan tentang bagaimana seharusnya memanage (mengelola) sumber daya manusia (Veithzal: 2005;1).

Pengertian manajemen sumber daya manusia menurut beberapa ahli, diantaranya:

a. Menurut Edin Flippo dalam Hasibuan $(2000 ; 11)$ Personal management is the planning, organizing, directing, and

P.ISSN: 1410-7988 E.ISSN: 2614-123X 
controlling of the procurement, development, compensation, integration, maintenance, and separation of human resources to the end that individual, organizational and societal objectives are accomplished. Manajemen sumber daya manusia adalah perencanaan, pengorganisasian, pengarahan dan pengendalian atas pengadaan tenaga kerja, pengembangan, kompensasi, integrasi, pemeliharaan, dan pemutusan hubungan kerja dengan sumber daya manusia untuk mencapai sasaran perorangan, organisasi, dan masyarakat.

b. Sedangkan menurut Hasibuan (2003;21), Manajemen sumber daya manusia adalah ilmu dan seni mengatur hubungan dan peranan tenaga kerja, agar efektif dan efisien membantu terujudnya tujuan.

c. Menurut Handoko (2001;4), Manajemen sumber daya manusia adalah penarikan, seleksi, pengembangan, pemeliharaan, dan penggunaan sumber daya manusia untuk mencapai baik tujuan-tujuan individu maupun Organisasi.

Jadi dapat disimpulkan bahwa pengertian manajemen sumber daya manusia atau manajemen personalia adalah proses perencanaan, pengorganisasian, pengarahan dan pengendalian atas pengadaan tenaga kerja, pengembangan, kompensasi, integrasi, pemeliharaan, dan pemutusan hubungan kerja dengan sumber daya manusia untuk mencapai sasaran perorangan, organisasi, dan masyarakat.

\section{Tujuan Manajemen Sumber Daya Manusia}

1. Tujuan Organisasional. Ditujukan untuk dapat mengenali keberadaan manajemen sumber daya manusia (MSDM) dalam memberikan kontribusi pada pencapaian efektivitas organisasi. Walaupun secara formal suatu departemen sumber daya manusia diciptakan untuk dapat membantu para manajer, namun demikian para manajer tetap

Eko dan Bisnis (Riau Economics and Business Reviewe) Volume 10, Nomor 4, 27 Desember 2019 bertanggung jawab terhadap kinerja karyawan. Departemen sumber daya manusia membantu para manajer dalam menangani hal-hal yang berhubungan dengan sumber daya manusia.

2. Tujuan Fungsional. Ditujukan untuk mempertahankan kontribusi departemen pada tingkat yang sesuai dengan kebutuhan organisasi. Sumber daya manusia menjadi tidak berharga jika manajemen sumber daya manusia memiliki kriteria yang lebih rendah dari tingkat kebutuhan organisasi.

3. Tujuan Sosial. Ditujukan untuk secara etis dan sosial merespon terhadap kebutuhankebutuhan dan tantangantantangan masyarakat melalui tindakan meminimasi dampak negatif terhadap organisasi. Kegagalan organisasi dalam menggunakan sumber dayanya bagi keuntungan masyarakat dapat menyebabkan hambatan-hambatan.

4. Tujuan Personal. Ditujukan untuk membantu karyawan dalam pencapaian tujuannya, minimal tujuan-tujuan yang dapat mempertinggi kontribusi individual terhadap organisasi. Tujuan personal karyawan harus dipertimbangkan jika parakaryawan harus dipertahankan, dipensiunkan, atau dimotivasi. Jika tujuan personal tidak dipertimbangkan, kinerja dan kepuasan karyawan dapat menurun dan karyawan dapat meninggalkan organisasi $(2008 ; 7)$.

\section{Fungsi Manajemen Sumber Daya Manusia}

Fungsi Manajemen Sumber Daya Manusia adalah: perencanaan, pengorganisasian, pengarahan, pengendalian.

1. Perencanaan. Perencanaan sumber daya manusia dalam organisasi merupakan seperangkat kegiatan yang berkaitan dengan perencanaan dan kebutuhan pegawai atau sumber daya manusia dari suatu organisasi di masa mendatang. Melalui estimasi jumlah dan jenis pegarwai yang diperlukan oleh seluruh bagian-bagian

P.ISSN: 1410-7988 E.ISSN: 2614-123X 
kepegawaian dapat menusun rencana secara lebih baik dalam hal-hal yang maenjadi lingkup pekerjaaannya, misalnya penarikan pegawai, seksi pegawai, dan lain sebagainya (Herman : 2006;19). Perencanaan Sumber Daya Manusia dapat di definisikan sebagai suatu cara untuk mencoba menetapkan keperluan-keperluan tenaga kerja baik secara kuantitas maupun kualitas untuk suatu periode waktu yang pasti dan menentukan bagaimana keperluankeperluan ini dapat terpenuhi (Donoghue; 2005;196). Seorang penulis berpendapat bahwa fokus perhatian perencanaan Sumber daya Manusia ialah langkah-langkah tertentu yang di ambil oleh manajemen yang lebih menjamin bahwa bagi organisasi yang tersedia tenaga kerja yang tepat untuk menduduki berbagai kedudukan, jabatan dan pekerjaan yang tepat (Manullang: 2005;27).

2. Pengorganisasian. Setelah programprogram di susun dan di tetapkan, perlu di bentuk organisasi yang akan melaksanakan program-program tadi. Organisasi adalah alat untuk mencapai tujuan oleh karena itu manajer personal harus membentuk satu organisasi dengan merancang struktur yang menggambarkan hubungan antara tugastugas antar pegawai dan antar faktorfaktor fisik.

3. Pengarahan. Di sebut juga dengan pemberian motivasi atau pemberian komando agar pegawai mulai bekerja. Pada dasarnya fungsi ini akan menumbuhkan kemauan pegawai untuk mulai bekerja secara aktif.

4. Pengendalian. Kegiatan-kegiatan yang biasa dilakukan dalam proses pengendalian berupa observasi terhadap kegiatan-kegiatan perencanaan di samping itu juga koreksi-koreksi terhadap penyimpangan yang terjadi selama rencana sedang di laksanakan (Sirait, 2006).

Eko dan Bisnis (Riau Economics and Business Reviewe) Volume 10, Nomor 4, 27 Desember 2019

\section{Pengawasan}

Berbagai fungsi manajemen dilaksanakan oleh para pimpinan dalam rangka mencapai tujuan organisasi. Fungsifungsi yang ada didalam manajemen diantaranya adalah fungsi perencanaan (Planning), fungsi pengorganisasian (Organizing), fungsi pelaksanaan (Actuating) dan fungsi pengawasan (Controlling) menurut Griffin (2004: 44). Keempat fungsi manajemen tersebut harus dilaksanakan oleh seorang manajer secara berkesinambungan, sehingga dapat merealisasikan tujuan organisasi. Pengawasan merupakan bagian dari fungsi manajemen yang berupaya agar rencana yang sudah ditetapkan dapat tercapai dengan efektif dan efisien.

Menurut Schermerhorn dalam Ernie dan Saefullah (2005: 317), mendifinisikan pengawasan merupakan sebagai proses dalam menetapkan ukuran kinerja dalam pengambilan tindakan yang dapat mendukung pencapaian hasil yang diharapkan sesuai dengan ukuran yang telah ditetapkan tersebut. Sedangkan menurut Mathis dan Jackson (2006: 303), menyatakan bahwa pengawasan merupakan sebagai proses pemantauan kinerja karyawan berdasarkan standar untuk mengukur kinerja, memastikan kualitas atas penilaian kinerja dan pengambilan informasi yang dapat dijadikan umpan balik pencapaian hasil yang dikomunikasikan ke para karyawan.

Defenisi ini tidak hanya terpaku pada apa yang direncanakan, tetapi mencakup dan melingkupi tujuan organisasi. Hal tersebut akan mempengaruhi sikap, cara, sistem, dan ruang lingkup pengawasan yang akan dilakukan oleh seorang manajer. Pengawasan sangat penting dilakukan oleh perusahaan dalam kegiatan operasionalnya untuk mencegah kemungkinan terjadinya penyimpangan- penyimpangan dengan melakukan tindakan koreksi terhadap penyimpangan tersebut untuk mencapai tujuan yang telah ditetapkan oleh perusahaan sebelumnya.

P.ISSN: 1410-7988 E.ISSN: 2614-123X 
Menurut Harahap (2001: 14), Pengawasan adalah keseluruhan sistem, teknik, cara yang mungkin dapat digunakan oleh seorang atasan untuk menjamin agar segala aktivitas yang dilakukan oleh dan dalam organisasi benar-benar menerapkan prinsip efisiensi dan mengarah pada upaya mencapai keseluruhan tujuan organisasi. Sedangkan menurut Maringan (2004: 61), pengawasan adalah proses dimana pimpinan ingin mengetahui hasil pelaksanaan pekerjaan yang dilakukan bawahan sesuai dengan rencana, perintah, tujuan, kebijakan yang telah ditentukan. Selain itu menurut Dessler (2009: 2), menyatakan bahwa pengawasan (Controlling) merupakan penyusunan standar - seperti kuota penjualan, standar kualitas, atau level produksi; pemeriksaan untuk mengkaji prestasi kerja aktual dibandingkan dengan standar yang telah ditetapkan; mengadakan tindakan korektif yang diperlukan.

Berdasarkan penjelasan para ahli diatas, maka dapat diambil kesimpulan bahwa pengawasan merupakan suatu tindakan pemantauan atau pemeriksaan kegiatan perusahaan untuk menjamin pencapaian tujuan sesuai dengan rencana yang ditetapkan sebelumnya dan melakukan tindakan korektif yang diperlukan untuk memperbaiki kesalahan-kesalahan yang ada sebelumnya. Pengawasan yang efektif membantu usaha dalam mengatur pekerjaan agar dapat terlaksana dengan baik. Fungsi pengawasan merupakan fungsi terakhir dari proses manajemen. Fungsi ini terdiri dari tugas-tugas memonitor dan mengevaluasi aktivitas perusahaan agar target perusahaan tercapai. Dengan kata lain fungsi pengawasan menilai apakah rencana yang ditetapkan pada fungsi perencanaan telah tercapai.

Menurut G.R Terry dalam Hasibuan (2001: 242) mengemukakan hal sebagai berikut : "Controlling can be defined as the process of determining what is to be accomplished, that is the standard; what is being accomplished, that is the performance, evaluating the performance and if necessary applying corrective measure so that

Eko dan Bisnis (Riau Economics and Business Reviewe) Volume 10, Nomor 4, 27 Desember 2019 performance takes place according to plans, that is, in conformity with the standard."

Pengawasan dapat didefinisikan sebagai proses penentuan, apa yang harus dicapai yaitu standar, apa yang sedang dilakukan yaitu pelaksanaan, menilai pelaksanaan dan melakukan perbaikanperbaikan, sehingga pelaksanaan sesuai dengan rencana yaitu selaras dengan standar.

Menurut Henry Fayol dalam Harahap (2001: 10) mengartikan pengawasan sebagai berikut:

"Control consist in verifying whether everything occurs in conformity with the plan adopted, the instruction issued and principles established. It has objective to point out weaknesses and errors in order to rectify then prevent recurrance".

Pengawasan mencakup upaya memeriksa apakah semua terjadi sesuai dengan rencana yang ditetapkan, perintah yang dikeluarkan, dan prinsip yang dianut .

Juga dimaksudkan untuk mengetahui kelemahan dan kesalahan agar dapat dihindari kejadiannya dikemudian hari. Menurut Siagian (2003: 30), bahwa pengawasan adalah memantau aktivitas pekerjaan karyawan untuk menjaga perusahaan agar tetap berjalan kearah pencapaian tujuan dan membuat koreksi jika diperlukan. Pengawasan secara umum berarti pengendalian terhadap perencanaan apakah sudah dilaksanakan sesuai tujuan atau penyimpangan dari tujuan yang diinginkan. Jika terjadi penyimpangan, pihak manajemen yang terkait dalam pengawasan harus memberikan petunjuk untuk melakukan perbaikan kerja, agar standar perencanaan tidak jauh menyimpang dari hasil yang diperoleh pada saat pelaksanaan.

\section{Tujuan Pengawasan}

Pelaksanaan kegiatan untuk mencapai tujuan yang telah ditetapkan memerlukan pengawasan agar perencanaan yang telah disusun dapat terlaksana dengan baik. Pengawasan dikatakan sangat penting

P.ISSN: 1410-7988 E.ISSN: 2614-123X 
karena pada dasarnya manusia sebagai objek pengawasan mempunyai sifat salah dan khilaf. Oleh karena itu manusia dalam organisasi perlu diawasi, bukan mencari kesalahannya kemudian menghukumnya, tetapi mendidik dan membimbingnya. Menurut Husnaini (2001: 400), tujuan pengawasan adalah sebagai berikut :
1. Menghentikan atau meniadakan kesalahan, penyimpangan, penyelewengan, pemborosan, dan hambatan.
2. Mencegah terulang kembalinya kesalahan, penyimpangan, pemborosan, dan hambatan.

3. Meningkatkan kelancaran operasi perusahaan. Melakukan tindakan koreksi terhadap kesalahan yang dilakukan dalam pencapaian kerja yang baik.

Menurut Maringan (2004: 61) menyatakan tujuan pengawasan adalah sebagai berikut:

a. Mencegah dan memperbaiki kesalahan, penyimpangan, ketidaksesuaian dalam pelaksanaan tugas yang dilakukan.

b. Agar pelaksanaan yang dilaksanakan sesuai dengan rencana yang telah ditetapkan sebelumnya.

Tujuan perusahaan dapat tercapai, jika fungsi pengawasan dilakukan sebelum terjadinya penyimpangan-penyimpangan sehingga lebih bersifat mencegah (prefentive control). Dibandingkan dengan tindakantindakan pengawasan sesudah terjadinya penyimpangan, maka tujuan pengawasan adalah menjaga hasil pelaksanaa

kegiatan sesuai dengan rencana. Ketentuanketentuan dan infrastruktur yang telah ditetapkan benar-benar diimplementasikan. Sebab pengawasan yang baik akan tercipta tujuan perusahaan yang efektif dan efisien.

\section{Jenis-jenis Pengawasan}

Menuurut Maringan (2004: 62), Pengawasan terbagi 4 yaitu:

a. Pengawasan dari dalam perusahaan. Pengawasan yang dilakukan oleh atasan untuk mengumpul data atau

Eko dan Bisnis (Riau Economics and Business Reviewe) Volume 10, Nomor 4, 27 Desember 2019 informasi yang diperlukan oleh perusahaan untuk menilai kemajuan dan kemunduran perusahaan.

b. Pengawasan dari luar perusahaan. Pengawasan yang dilakukan oleh unit diluar perusahaan. Ini untuk kepentingan tertentu.

c. Pengawasan Preventif. Pengawasan dilakukan sebelum rencana itu dilaksakaan. Dengan tujuan untuk mengacah terjadinya kesalahan/ kekeliruan dalam pelaksanaan kerja.

d. Pengawasan Represif. Pengawasan yang dilakukan setelah adanya pelaksanaan pekerjaan agar hasilnya sesuai dengan yang direncanakan.

Menurut Ernie dan Saefullah (2005: 327), jenis pengawasan terbagi atas 3 yaitu:

a. Pengawasan Awal. Pengawasan yang dilakukan pada saat dimulainya pelaksanaan pekerjaan. Ini dilakukan untuk mencegah terjadinya penyimpangan dalam pelaksanaan perkerjaan.

b. Pengawasan Proses. Pengawasan dilakukan pada saat sebuah proses pekerjaan tengah berlangsung untuk memastikan apakah pekerjaan tengah berlangsung untuk memastikan apakah pekerjaan yang dilaksanakan sesuai dengan tujuan ang ditetapkan.

c. Pengawasan Akhir. Pengawasan yang dilakukan pada saat akhir proses pengerjaan pekerjaan.

Adapun indikator pengawasan antara lain :

1. Menentukan ukuran/standar

2. Mengadakan penilaian/ pengukuran pekerjaan

3. Perbandingan antara pelaksanaan pekerjaan

4. Melakukan tindakan koreksi/ perbaikan

Berdasarkan beberapa pengertian diatas; maka dapat ditetapkan indicator pengawasan menurut (Manulang dalam Elpia Ningsih 2014: 14) adalah;

a. Standar pengukuran pengawasan dalam perencanaan, Untuk menetapkan standar pengukuran pengawasan dalam

P.ISSN: 1410-7988 E.ISSN: 2614-123X 
perencanaan harus dilakukan standar kerja yang telah ditetapkan oleh Pimpinan agar tidak terjadi penyimpangan atau kesalahan dalam melaksanakan pekerjaan yang direncanakan. Oleh karena itu, standar kerja ini sangat diperlukan agar perencanaan berjalan dengan baik sehingga standar pengukuran ini dapat dicapai sesuai dengan rencana yang telah ditetapkan. Dengan demikian standarstandar pengawasan dalam rangka ini dimaksud sebagai satu pengukuran yang dapat digunakan sebagai patokan bagi pegawai dalam rangka memulai pekerjaan.

b. Penentuan pengukuran pelaksanaan kegiatan, Artinya cara-cara untuk mengukur pelaksanaan seperti beberapa syarat minimal melaksanakan pengawasan dalam satuan waktu seperti satu kali seminggu atau beberapa kali sebulan atau mungkin beberapa jam setiap hari.

c. Pembanding pelaksanan kegiatan dengan standar-standar dan penganalisaan penyimpangan-penyimpangan. Artinya membandingkan antara konsep dan implementasi tentang kegiatan pengawasan.

d. Tindakan korektif. Tindakan korektif ini dimaksudkan korektif internal yaitu mengevaluasi berbagai metode pengawasan yang ada seperti standar yang terlalu tinggi, dan eksternal yaitu memberi sanksi kepada bawahan.

\section{Kinerja}

Kinerja berasal dari kata job performance atau actual performanceyang berarti prestasi kerja atau prestasi sesungguhnya yang dicapai oleh seseorang. Pengertian kinerja (prestasi kerja) adalah hasil kerja secara kualitas dan kuantitas yang dicapai oleh seorang pegawai dalam melaksanakan fungsinya sesuai dengan tanggung jawab yang diberikan kepadanya. Performance atau kinerja merupakan hasil atau keluaran dari suatu proses (Nurlaila, 2010:71).

Eko dan Bisnis (Riau Economics and Business Reviewe) Volume 10, Nomor 4, 27 Desember 2019
Menurut pendekatan perilaku dalam manajemen, kinerja adalah kuantitas atau kualitas sesuatu yang dihasilkan atau jasa yang diberikan oleh seseorang yang melakukan pekerjaan (Luthans, 2005:165).

Kinerja merupakan prestasi kerja, yaitu perbandingan antara hasil kerja dengan standar yang ditetapkan (Dessler, 2000:41). Kinerja adalah hasil kerja baik secara kualitas maupun kuantitas yang dicapai oleh seseorang dalam melaksanakan tugas sesuai tanggung jawab yang diberikan (Mangkunagara, 2002:22).

Kinerja adalah hasil atau tingkat keberhasilan seseorang secara keseluruhan selama periode tertentu dalam melaksanakan tugas dibandingkan dengan berbagai kemungkinan, seperti standar hasil kerja, target atau sasaran atau kriteria yang telah ditentukan terlebih dahulu telah disepakati bersama (Rivai dan Basri, 2005:50). Sedangkan Mathis dan Jackson (2006:65) menyatakan bahwa kinerja pada dasarnya adalah apa yang dilakukan atau tidak dilakukan pegawai. Manajemen kinerja adalah keseluruhan kegiatan yang dilakukan untuk meningkatkan kinerja perusahaan atau organisasi, termasuk kinerja masing-masing individu dan kelompok kerja di perusahaan tersebut.

\section{Faktor-faktor yang Mempengaruhi Kinerja}

Menurut Payaman S Simanjuntak (2005), kinerja setiap orang dipengaruhi oleh banyak faktor yang dapat di golongkan dalam 3 kelompok yaitu kompetensi individu orang yang bersangkutan, dukungan organisasi dan dukungan manajemen.

1. Faktor kompetensi individu. Kompetensi individu adalah kemampuan dan keterampilan melakukan kerja. Kompetensi seseorang dipengaruhi oleh beberapa faktor yang dapat dikelompokkan dalam dua golongan, yaitu :
a. Kemampuan dan Keterampilan Kerja. 
Kemampuan dan keterampilan kerja setiap orang dipengaruhi oleh kesehatan fisik dan jiwa individu yang bersangkutan, pendidikan, akumulasi pelatihan, serta pengalaman kerjanya. Kesehatan fisik dan jiwa individu membuat orang mampu dan tahan bekerja keras dan lama. Sebaliknya, pekerja yang kekurangan gizi akan cepat lemah dan lelah, serta tidak mampu melakukan pekerjaan berat. Demikian juga dengan gangguan kejiwaan akibat rasa frustasi dan masalah-masalah sosial ekonomi membuat yang bersangkutan tidak konsisten dan tidak terkonsentrasi melakukan pekerjaan. Pendidikan dan pelatihan merupakan bagian dari investasi sumber daya manusia (human investment). Semakin lama waktu yang digunakan seseorang untuk pendidikan dan pelatihan maka semakin tinggi kemampuan atau kompetensinya melakukan pekerjaan, dan demikian semakin tinggi kinerjanya. Pengalaman kerja dapat memperdalam dan memperluas kemampuan kerja. Semakin sering seseorang melakukan pekerjaan yang sama, semakin terampil dan semakin cepat dia menyelesaikan pekerjaan tersebut. Semakin banyak macam pekerjaan yang dilakukan seseorang, pengalaman kerjanya semakin kaya dan luas, dan memungkinkan peningkatan kinerja.

b. Motivasi dan Etos Kerja. Motivasi dan etos kerja sangat penting mendorong semangat kerja. Motivasi dan etos kerja dipengaruhi oleh latar belakang keluarga, lingkungan masyarakat, budaya dan nilai - nilai agama yang dianutnya. Seseorang yang melihat pekerjaan sebagai beban dan keterpaksaaan akan mempunyai kinerja yang rendah. Sebaliknya, seseorang yang memandang pekerjaan sebagai kebutuhan, tantangan dan prestasi akan menghasilkan kinerja yang tinggi. Sedangkan menurut Barelson dan Steiner dikutip oleh Siswanto Sastrohadiwiryo (2003) mendefinisikan motivasi sebagai keadaan kejiwaan dan sikap mental manusia yang memberikan energi, mendorong kegiatan atau menggerakkan dan mengarah atau menyalurkan perilaku kearah mencapai kebutuhan yang memberi kepuasan atau mengurangi ketidakseimbangan. Kebutuhan tersebut timbul akibat adanya berbagai hubungan. Kebutuhan dapat berwujud fisik- biologis serta sosial ekonomis. Akan tetapi yang lebih penting adalah adanya kebutuhan-kebutuhan (needs) yang bersifat sosial-psikis, misalnya penghargaan, pengakuan, keselamatan, perlindungan, keamanan, dan jaminan sosial. Pada dasarnya motivasi dapat memicu karyawan untuk bekerja keras sehingga dapat mencapai tujuan mereka. Hal ini akan meningkatkan produktivitas kerja karyawan sehingga berpengaruh pada pencapaian tujuan perusahaan. Sumber motivasi ada tiga faktor, yakni kemungkinan untuk berkembang, jenis pekerjaan, dan apakah mereka dapat merasa bangga menjadi bagian dari perusahaan tempat mereka bekerja. Disamping itu terdapat beberapa aspek yang berpengaruh terhadap motivasi kerja karyawan, yakni : rasa aman dalam bekerja, mendapatkan gaji yang adil dan kompetitif, lingkungan kerja yang menyenangkan, penghargaan atas prestasi kerja dan perlakuan adil dari manajemen. Dengan melibatkan karyawan dalam pengambilan keputusan, pekerjaan yang menarik menantang, kelompok dan rekan kerja yang 
menyenangkan serta kejelasan akan standar keberhasilan.

2. Faktor Dukungan Organisasi. Kinerja setiap orang juga tergantung pada dukungan organisasi dalam bentuk pengorganisasian, penyediaan sarana dan prasarana kerja, pemilihan teknologi, kenyamanan lingkungan kerja, serta kondisi dan syarat kerja. Pengorganisasian dimaksudkan untuk memberi kejelasan bagi setiap orang tentang sasaran yang harus dicapai dan apa yang harus dilakukan untuk mencapai sasaran tersebut. Setiap orang perlu memiliki dan memahami uraian jabatan dan tugas yang jelas.

Demikian juga penyediaan sarana dan alat kerja langsung mempengaruhi kinerja setiap orang. Penggunaan peralatan dan teknologi maju sekarang ini bukan saja dimaksudkan untuk meningkatkan kinerja, akan tetapi juga dipandang untukmemberikan kemudahan dan kenyamanan kerja.

Kondisi kerja mencakup kenyamanan lingkungan kerja, aspek keselamatan dan kesehatan kerja, syarat - syarat kerja, sistem pengupahan dan jaminan sosial, serta keamanan serta keharmonisan hubungan industrial. Hal-hal tersebut mempengaruhi kenyamanan untuk melakukan tugas yang lebih lanjut mempengaruhi kinerja setiap orang. Program keselamatan dan kesehatan kerja perlu ditingkatkan bukan saja untuk menghindari kecelakaan kerja, kerusakan alat dan gangguan produk, akan tetapi juga untuk meningatkan kinerja karyawan atau pekerja.

Syarat - syarat kerja yang memuat hak dan kewajiban serta kewenangan dan kewajiban pengusaha akan memberikan kepastian bagi pekerja untuk melaksanakan tugasnya dengan baik dan penuh tanggung jawab. Pemberian kompensasi yang adil dan layak melalui sistem pengupahan akan mendorong setiap pekerja meningkatkan kinerjanya. Dalam hubungan industrial yang aman dan harmonis kinerja pekerja tidak perlu terganggu oleh demontrasi dan pemogokan.

Kompensasi merupakan sesuatu yang diterima karyawan sebagai pengganti

Eko dan Bisnis (Riau Economics and Business Reviewe) Volume 10, Nomor 4, 27 Desember 2019 kontribusi jasa mereka pada perusahaan. Pemberian kompensasi merupakan salah satu pelasanaan fungsi MSDM yang berhubungan dengan semua jenis pemberian penghargaan individual sebagai pertukaran dalam melakukan tugas keorganisasian. Kompensasi merupakan biaya utama atas keahlian atau pekerjaan dan kesetiaan dalam bisnis perusahaan. Kompensasi menjadi alasan utama mengapa kebanyakan orang mencari pekerjaan (Veithzal Rivai, 2005).

Adapun komponen - komponen kompensasi yaitu : Gaji, adalah balas jasa dalam bentuk uang yang diterima karyawan sebagai konsekuensi dari kedudukannya sebagai seorang karyawan yang memberikan sumbangan tenaga dan pikiran dalam mencapai tujuan perusahaan. Atau dapat juga dikatakan sebagai bayaran tetap yang diterima seseorang dari keanggotanya dalam sebuah perusahaan. Upah, merupakan imbalan finansial langsung yang dibayarkan kepada karyawan berdasarkan jam kerja, jumlah barang yang dihasilkan atau banyaknya pelayanan yang diberikan. Jadi tidak seperti gaji yang jumlahnya relatif tetap, besarnya upah dapat berubah ubah tergantung pada ukuran yang dihasilkan. Insentif, merupakan imbalan langsung yang dibayarkan kepada karyawan karna kinerjanya melebihi standar yang ditentukan. Insentif merupakan bentuk lain dari upah langsung di luar upah dan gaji yang merupakan kompensasi tetap, yang biasa disebut kompensasi berdasarkan kinerja (pay for performance plan). Kompensasi Tidak Langsung, merupakan kompensasi tambahan yang diberikan berdasarkan kebijakan perusahaan terhadap semua karyawan sebagai upaya meningkatkan kesejahteraan para karyawan. Contohnya, berupa fasilitas-fasilitas seperti : Asuransi-asuransi, tunjangan-tunjangan, uang pensiun dan lain sebagainya.

3. Faktor Dukungan Manajemen. Kinerja perusahaan dan kinerja setiap orang juga sangat tergantung pada kemampuan manajerial para

P.ISSN: 1410-7988 E.ISSN: 2614-123X 
manajemen atau pimpinan, baik dengan membangun sistem kerja dan hubungan industrial yang aman dan harmonis, maupun dengan mengembangkan kompetensi pekerja, pengembangan kompetensi dapat dilakukan dengan pelatihan, demikian juga dengan menumbuhkan motivasi dan mobilisasi seluruh karyawan untuk bekerja secara optimal.

Menurut Veitzhal Rivai (2005) pelatihan secara singkat didefinisikan sebagai suatu kegiatan untuk meningkatkan kinerja saat ini dan kinerja di masa mendatang. Sedangkan pengembangan manajemen adalah suatu proses bagaimana manajemen mendapatkan pengalaman, keahlian dan sikap untuk menjadi atau meraih sukses sebagai pemimpin dalam organisasi mereka. Karena itu, kegiatan pengembangan ditujukan membantu karyawan untuk dapat menangani jawabannya di masa mendatang, dengan memperhatikan tugas dan kewajiban yang di hadapai sekarang.

Kinerja merupakan suatu konsep yang multicated (banyak dimensi) artinya bahwa kinerja banyak dipengaruhi oleh berbagai faktor. Faktor-faktor tersebut adalah faktor lingkungan internal organisasi, faktor lingkungan eksternal, dan faktor internal karyawan atau pegawai (Wirawan, 2009).

1. Faktor internal pegawai. Yaitu faktor faktor dari dalam diri pegawai yang merupakan faktor bawaan dari lahir dan faktor yang diperoleh ketika ia berkembang. Faktor - faktor bawaan, misalnya bakat, sifat pribadi, serta keadaan fisik dan kejiwaan. Sementara itu, faktorfaktor yang diperoleh, misalnya pengetahuan, keterampilan, etos kerja, pengalaman kerja, dan motivasi kerja.

2. Faktor faktor lingkungan internal organisasi. Dalam melaksanakan tugasnya, pegawai memerlukan dukungan organisasi tempat ia bekerja. Dukungan tersebut sangat memengaruhi tinggi rendahnya kinerja pegawai. Sebaliknya, jika sistem kompensasi dan iklim kerja organisasi buruk, kinerja karyawan akan menurun. Faktor internal organisasi

Eko dan Bisnis (Riau Economics and Business Reviewe) Volume 10, Nomor 4, 27 Desember 2019 lainnya misalnya strategi organisasi, dukungan sumber daya yang diperlukan untuk melaksanakan pekerjaan, serta sistem manajemen dan kompensasi. Oleh karena itu, manajemen organisasi harus menciptakan lingkungan internal organisasi yang kondusif sehingga dapat mendukung dan meningkatkan produktivitas karyawan.

3. Faktor lingkungan eksternal organisasi. Faktor-faktor lingkungan eksternal organisasi adalah keadaan, kejadian, atau situasi yang terjadi di lingkungan eksternal organisasi yang memengaruhi kinerja karyawan. Misalnya, krisis ekonomi dan keuangan yang terjadi di Indonesia tahun 1997 meningkatkan inflasi, menurunkan nilai nominal upah dan gaji karyawan, dan selanjutnya menurunkan daya beli karyawan. Jika inflasi tidak diikuti dengan kenaikan upah atau gaji para karyawan yang sepadan dengan tingkat inflasi, maka kinerja mereka akan menurun.

Budaya masyarakat juga merupakan faktor eksternal yang mempengaruhi kinerja karyawan. Misalnya budaya alon-alon asal kelakon dan mangan ora mangan asal kumpul mempengaruhi kinerja manusia Indonesia. Hal tersebut dapat menjelaskan penyebab kinerja orang Indonesia rendah, misalnya jika dibandingkan dengan kinerja bangsa Jepang. Karena budaya tersebut, etos kerja manusia Indonesia lebih rendah jika dibandingkan dengan etos kerja bangsa lain.

\section{Karakteristik Kinerja Karyawan}

Karakteristik orang yang mempunyai kinerja tinggi adalah sebagai berikut (Mangkunegara, 2002:68):

1. Memiliki tanggung jawab pribadi yang tinggi.

2. Berani mengambil dan menanggung resiko yang dihadapi.

3. Memiliki tujuan yang realistis.

4. Memiliki rencana kerja yang menyeluruh dan berjuang untuk merealisasi tujuannya. 
5. Memanfaatkan umpan balik (feed back) yang konkrit dalam seluruh kegiatan kerja yang dilakukannya.

6. Mencari kesempatan untuk merealisasikan rencana yang telah diprogramkan.

\section{Indikator Kinerja Karyawan}

Indikator untuk mengukur kinerja karyawan secara individu ada enam indikator, yaitu (Robbins, 2006:260):

1. Kualitas. Kualitas kerja diukur dari persepsi karyawan terhadap kualitas pekerjaan yang dihasilkan serta kesempurnaan tugas terhadap keterampilan dan kemampuan karyawan.

2. Kuantitas. Merupakan jumlah yang dihasilkan dinyatakan dalam istilah seperti jumlah unit, jumlah siklus aktivitas yang diselesaikan.

3. Ketepatan waktu. Merupakan tingkat aktivitas diselesaikan pada awal waktu yang dinyatakan, dilihat dari sudut koordinasi dengan hasil output serta memaksimalkan waktu yang tersedia untuk aktivitas lain.

4. Efektivitas. Merupakan tingkat penggunaan sumber daya organisasi (tenaga, uang, teknologi, bahan baku) dimaksimalkan dengan maksud menaikkan hasil dari setiap unit dalam penggunaan sumber daya.

5. Kemandirian. Merupakan tingkat seorang karyawan yang nantinya akan dapat menjalankan fungsi kerjanya Komitmen kerja. Merupakan suatu tingkat dimana karyawan mempunyai komitmen kerja dengan instansi dan tanggung jawab karyawan terhadap kantor.

Indikator kinerja karyawan menurut Robert L. Mathis dan John H. Jackson (2006:378) adalah sebagai berikut:

1. Kuantitas. Kuantitas merupakan jumlah yang dihasilkan dinyatakan dalam istilah seperti jumlah unit, jumlah siklus aktivitas yang diselesaikan. Kuantitas yang diukur dari persepsi pegawai

Eko dan Bisnis (Riau Economics and Business Reviewe) Volume 10, Nomor 4, 27 Desember 2019 terhadap jumlah aktivitas yang ditugaskan beserta hasilnya.

2. Kualitas. Kualitas adalah ketaatan dalam prosedur, disiplin, dedikasi. Tingkat dimana hasil aktivitas yang dikehendaki mendekati sempurna dalam arti menyesuaikan beberapa cara ideal dari penampilan aktivitas, maupun memenuhi tujuan-tujuan yang diharapkan dari suatu aktivitas. Kualitas kerja diukur dari persepsi pegawai terhadap kualitas pekerjaan yang dihasilkan serta kesempurnaan tugas terhadap ketrampilan dan kemampuan pegawai.

3. Keandalan. Keandalan adalah kemampuan untuk melakukan pekerjaan yang disyaratkan dengan supervisi minimum. Menurut Zeithaml \& Berry dalam Journal of Marketing ( dalam Sudarmanto, 2009:14) kehandalan yakni mencakp konsistensi kinerja dan kehandalan dalam pelayanan; akurat, benar dan tepat.

4. Kehadiran. Kehadiran adalah keyakinan akan masuk kerja setiap hari dan sesuai dengan jam kerja.

5. Kemampuan bekerja sama. Kemampuan bekerja sama adalah kemampuan seorang tenaga kerja untuk bekerja bersama dengan orang lain dalam menyelesaikan suatu tugas dan pekerjaan yang telah ditetapkan sehingga mencapai daya guna dan hasil guna yang sebesar-besarnya.

\section{Pengaruh Pengawasan terhadap Kinerja}

Fungsi pengawasan dalam penyelenggaraan manajemen perusahaan (corporation) sangat diperlukan untuk mencegah berbagai kendala pelaksanaan setiap kegiatan organisasi di lingkungan perusahaan atau badan usaha baik milik pemerintah maupun swasta. Efek yang diharapkan dari dilaksanakannya fungsi pengawasan adalah meningkatnya kinerja perusahaan dan prestasi kerja karyawan. Bacal (2005:229), menjelaskan bahwa kinerja perusahaan diawali dengan peningkatan kinerja karyawan. Kinerja

P.ISSN: 1410-7988 E.ISSN: 2614-123X 
karyawan berkaitan dengan kemampuan masing-masing karyawan dalam melaksanakan tugas-tugasnya secara tepat waktu dan sesuai dengan hasil yang ditentukan. Proses mencapai kinerja yang sesuai dengan hasil yang secara standard telah ditentukan perusahaan melibatkan penggunaan logika untuk mencari cara-cara yang paling ekonomis untuk melaksanakan tugas kerja, peralatan dan bahan kerja, kondisi lingkungan dan ruang serta cara-cara yang mudah dalam melaksanakan tugas kerja.

Proses peningkatan kinerja sebagaimana di atas merupakan suatu indicator yang merupakan suatu aktivitas terencana dan berkesinambungan serta berhubungan dengan orang lain, maka untuk mencapai kinerja perlu dilakukan pengawasan untuk mengurangi munculnya kesalahan dan memperbaiki metode yang dinilai kurang efektif.

Menurut Schermerhorn dalam Ernie dan Saefullah (2005:317), mendifinisikan pengawasan merupakan sebagai proses dalam menetapkan ukuran kinerja dalam pengambilan tindakan yang dapat mendukung pencapaian hasil yang diharapkan sesuai dengan ukuran yang telah ditetapkan tersebut.

Sedangkan menurut Mathis dan Jackson (2006:303), menyatakan bahwa pengawasan merupakan sebagai proses pemantauan kinerja karyawan berdasarkan standar untuk mengukur kinerja, memastikan kualitas atas penilaian kinerja dan pengambilan informasi yang dapat dijadikan umpan balik pencapaian hasil yang dikomunikasikan ke para karyawan.

\section{METODE}

\section{Lokasi Penelitian}

Penelitian ini dilaksanakan di Dinas Perindustrian dan Perdagangan Provinsi Riau Gedung Menara Lancang Kuning Lt 5 Jalan Jenderal Sudirman No. 460 Pekanbaru Riau 28116, Telp. 0761-22900. Alasan pemilihan lokasi karena Dinas Perindustrian dan Perdagangan Provinsi Riau memiliki jumlah pegawai yang cukup banyak.

Eko dan Bisnis (Riau Economics and Business Reviewe) Volume 10, Nomor 4, 27 Desember 2019

\section{Jenis Sumber Data}

Berdasarkan sumbernya data dapat digolongkan menjadi dua, yaitu data primer dan data sekunder.

\section{Data Primer}

Data primer adalah data yang diperoleh langsung dari responden atau objek yang diteliti atau ada hubungannya dengan objek yang diteliti. Data tersebut bisa diperoleh langsung dari personel yang diteliti dan dapat pula berasal dari lapangan. Data langsung dari personel tergantung dari objek mana yang diteliti, misalnya objeknya menyangkut kesejahteraan pegawai suatu perusahaan, maka data primer yang diperlukan berasal dari karyawan perusahaan tersebut. Jika objek menyangkut pertanian, data primer berasal dari petani. Selain melalui personel data primer juga bisa diperoleh melalui pengamatan atau percobaan di lapangan melalui laboratorium.

\section{Data Sekunder}

Data sekunder adalah data yang lebih dahulu dikumpulkan dan dilaporkan oleh orang atau instansi di luar dari penelitian sendiri, walaupun yang dikumpulkan itu sesungguhnya adalah data asli. Data sekunder bisa diperoleh dari instansi-instansi, perpustakaan, maupun dari pihak lainnya.

\section{Populasi dan Sampel}

Populasi adalah kelompok atau kumpulan individu-individu atau obyek penelitian yang memiliki standar-standar tertentu dari ciri-ciri yang telah ditetapkan sebelumnya. Berdasarkan kualitas dan ciri tersebut, populasi dapat dipahami sebagai sekelompok individu atau obyek pengamatan yang minimal memiliki satu persamaan karakteristik (Cooper dan Emory, 1995). Dengan kata lain populasi merupakan kumpulan individu atau obyek penelitian yang mempunyai kualitaskualitas serta cirri-ciri yang telah ditetapkan. Populasi adalah wilayah generalisasi yang terdiri atas obyek atau subyek yang mempunyai kualitas dan karakteristik tertentu yang ditetapkan oleh 
peneliti untuk dipelajari dan kemudian ditarik kesimpulannya (Sugiyono, 2002).

Populasi dari penelitian ini adalah Pegawai Dinas Perindustrian dan Perdagangan Provinsi Riau, sebanyak 223 orang. Sampel adalah sebagian dari seluruh elemen-elemen atau individu-individu yang terdapat pada populasi. Karena berbagai keterbatasan, peneliti tidak mungkin meneliti atau mengumpulkan data dari seluruh anggota populasi. Jadi, peneliti tidak bisa melakukan studi populasi. Maka peneliti mengambil sebagian daripada seluruh anggota populasi tersebut. Salah satu cara menentukan besaran sampel yang memenuhi hitungan adalah yang dirumuskan oleh Slovin (Steph Ellen, EHOW BLOG, 2010; dengan rujukan Principles and Methods of Research; Ariola et al. (eds.); 2006) sebagai berikut.

$$
n=\frac{N}{1+N e^{2}}
$$

Dimana:

$\mathrm{n} \quad=$ Ukuran sampel

$\mathrm{N} \quad=$ Besar populasi asumsi pelanggan

$\mathrm{e}=$ Taraf kesalahan (error) sebesar 0,10 $(10 \%)$

$$
\begin{aligned}
& =223 /\left(1+223 \times 0,1^{\wedge} 2\right) \\
& =69,04 \text { dibulatkan menjadi } 69
\end{aligned}
$$

Dalam penelitian ini peneliti menggunakan sampel Stratified Random Sampling,

\section{Teknik Pengumpulan Data}

Data dalam penelitian ini dapat dikumpulkan dengan cara sebagai berikut :

\section{Wawancara}

Wawancara merupakan teknik pengumpulan data dimana pewawancara (peneliti atau yang diberi tugas melakukan pengumpulan data) dalam mengumpulkan data mengajukan suatu pertanyaan kepada yang diwawancarai.

\section{Analisis Data}

\section{Uji Reliabilitas}

Pengertian Reliabilitas adalah untuk mengukur suatu kuesioner yang merupakan indikator dari variabel atau konstruk. Butir pertanyaan dikatakan reliabel atau andal apabila jawaban seseorang terhadap pertanyaan adalah konsisten. Pengukuran reliabilitas dilakukan dengan dua cara, yaitu:

1. REPEATED MEASURE atau pengukuran ulang. Dalam waktu yang berbeda, responden diberi butir pertanyaan dan alternatif jawaban yang sama. Butir pertanyaan dikatakan andal jika jawabannya sama.

2. ONE SHOT atau pengukuran sekali saja. Pengukuran keandalan butir pertanyaan dengan skali menyebarkan kuesioner terhadap responden, dan hasil skornya diukur korelasinya antar skor jawaban pada butir pertanyaan yang sama dengan bantuan komputer STATISTICAL PROGRAM FOR SOCIETY SCIENCE(SPSS), dengan fasilitas CRONBACH ALPHA (a). Suatu konstruk atau variabel dikatakan reliabel jika memberikan nilai CRONBACH ALPHA > 0,60.

\section{Regresi Linear Sederhana}

Regresi Linear Sederhana adalah Metode Statistik yang berfungsi untuk menguji sejauh mana hubungan sebab akibat antara Variabel Faktor Penyebab (X) terhadap Variabel Akibatnya. Faktor Penyebab pada umumnya dilambangkan dengan $\mathrm{X}$ atau disebut juga dengan Predictor sedangkan Variabel Akibat dilambangkan dengan $\mathrm{Y}$ atau disebut juga dengan Response. Regresi Linear Sederhana atau sering disingkat dengan SLR (Simple Linear Regression) juga merupakan salah satu Metode Statistik yang dipergunakan dalam produksi untuk melakukan peramalan ataupun prediksi tentang karakteristik kualitas maupun Kuantitas.

Model Persamaan Regresi Linear Sederhana adalah seperti berikut ini :

$$
\begin{aligned}
& Y=a+b X \\
& \text { Dimana : } \\
& Y=\text { Variabel Response atau } \\
& \text { Variabel Akibat (Dependent) } \\
& X=\text { Variabel Predictor atau Variabel }
\end{aligned}
$$$$
\text { P.ISSN: 1410-7988 E.ISSN: 2614-123X }
$$ 
Faktor Penyebab (Independent)

$\mathrm{a}=$ konstanta

$\mathrm{b}=$ koefisien regresi (kemiringan);

besaran Response yang ditimbulkan

oleh Predictor.

Nilai-nilai a dan b dapat dihitung

dengan menggunakan Rumus

dibawah ini :

$$
\begin{aligned}
& \mathrm{a}=\frac{\left(\sum \mathrm{y}\right)\left(\sum \mathrm{x}^{2}\right)-\left(\sum \mathrm{x}\right)\left(\sum \mathrm{xy}\right)}{\mathrm{n}\left(\Sigma \mathrm{x}^{2}\right)-(\Sigma \mathrm{x})^{2}} \\
& \dot{\mathrm{b}}=\frac{\mathrm{n}(\Sigma \mathrm{xy})-(\Sigma \mathrm{x})(\Sigma \mathrm{y})}{\mathrm{n}\left(\Sigma \mathrm{x}^{2}\right)-(\Sigma \mathrm{x})^{2}}
\end{aligned}
$$

\section{Uji t}

Untuk menguji kemaknaan koefisien parsial digunakan uji t.

Apabila t

hitung $>\mathrm{t}_{\text {tabel }}$ pada taraf signifikan 5\%, maka dapat dikatakan bahwa variabel bebas dapat menerangkan variabel terikat atau dengan kata lain ada pengaruh antara variabel bebas dengan variabel terikat. Sebaliknya apabila $t$ hitung $<\mathrm{t}_{\text {tabel }}$ pada taraf signifikan 5\%, maka dapat dikatakan bahwa variabel bebas tidak dapat menjelaskan variabel terikatnya atau dengan kata lain tidak ada pengaruh antara variabel bebas dengan variabel terikat.

Rumus uji ini adalah sebagai berikut :

$$
t=\frac{r_{y 1,2} \sqrt{N-3}}{\sqrt{1-r_{y 1,2}^{2}}}
$$

Untuk mencari besarnya sumbangan variabel disiplin kerja terhadap efektivitas kerja dan pengaruh pengawasan kerja terhadap efektivitas kerja digunakan rumus koefisien determinasi secara parsial $\left(\mathrm{r}^{2}\right)$ dengan rumus sebagai berikut :

$$
\mathrm{r}^{2}=1-\frac{\sum(Y-y)}{\sum(Y-y)^{2}}
$$

\section{Keterangan :}

$\mathrm{r}^{2}=$ Koefisien determinasi secara parsial

$\mathrm{Y}=$ Nilai rata-rata $\mathrm{Y}$

$\mathrm{y}=$ Nilai estimasi y (Algifari, 1997: 6).

\section{Koefisien Determinasi $\left(\mathbf{R}^{2}\right)$}

Koefisien determinasi adalah salah satu nilai statistik yang dapat digunakan untuk mengetahui apakah ada pengaruh Eko dan Bisnis (Riau Economics and Business Reviewe) Volume 10, Nomor 4, 27 Desember 2019 antara dua variabel. Nilai kopefisien determinasi yang biasanya diberi simbol $\mathrm{R}^{2}$ menunjukkan hubungan pengaruh dua variabel yaitu variabel independen dan variabel dependen dari hasil perhitungan tertentu (J.Supranto,2009:336)

\section{HASIL}

\section{Uji Reliabilitas}

Uji reliabilitas digunakan untuk mengetahui apakah jawaban responden dari waktu-kewaktu memiliki jawaban yang sama/konsisten atau tidak. Dalam penelitian ini metode yang digunakan adalah dengan metode Cronbach's Alpha yang mensyaratkan nilai Cronbach's Alpha > 0,60 maka data adalah relibel atau dapat dipercaya. Berikut hasil uji reliabilitas :

\section{Tabel 4 Uji Reliabilitas}

\begin{tabular}{|c|l|c|c|}
\hline No & Variabel & Cronbach's Alpha & Keterangan \\
\hline 1 & Kinerja & 0.872 & $\begin{array}{c}\text { Reliabel/ } \\
\text { konsisten }\end{array}$ \\
\hline 2 & Pengawasan & 0.870 & Reliabel/konsisten \\
\hline
\end{tabular}

Sumber, hasil SPSS 19

Dari tabel 4 dapat dijelaskan bahwa variabel kinerja memiliki nilai sebesar 0.872 dan variabel pengawasan sebesar 0.870. Karena nilai lebih besar dari 0,60 maka dapat disimpulkan bahwa semua variabel dalam penelitian ini adalah reliabel atau konsisten, artinya semua pernyataannya dapat dipercaya.

\section{Regresi Linier Sederhana}

Analisis regresi linier Sederhana

\begin{tabular}{|c|c|c|c|c|c|c|}
\hline & & \multicolumn{2}{|c|}{$\begin{array}{l}\text { Unstandardized } \\
\text { Coefficients }\end{array}$} & \multirow{2}{*}{$\begin{array}{c}\begin{array}{c}\text { Standardized } \\
\text { Coefficients }\end{array} \\
\text { Beta } \\
\end{array}$} & \multirow[b]{2}{*}{$\mathrm{T}$} & \multirow[b]{2}{*}{ Sig. } \\
\hline \multicolumn{2}{|c|}{ Model } & $\mathrm{B}$ & Std. Error & & & \\
\hline \multirow[t]{2}{*}{1} & (Constant) & 11.206 & 2.983 & & 3.757 & .000 \\
\hline & Pengawasan & .608 & .063 & .762 & 9.626 & .000 \\
\hline
\end{tabular}
digunakan untuk menentukan arah hubungan yang linier antara variabel bebas terhadap variabel terikat.:

Tabel 5 Analisis Regresi Linier sederhana

Sumber, hasil SPSS 19

Berdasarkan tabel 5 diperoleh persamaan regresi linier sederhana adalah sebagai berikut : $\mathrm{Y}=11.206+0.608 \mathrm{X}$ 
Persamaan tersebut dapat diartikan sebagai berikut :

a. Konstanta sebesar 11.206 artinya tanpa adanya pengawasan, maka kinerja pegawai pada Kantor Dinas Perindustrian dan Perdagangan Provinsi Riau sebesar 11.206 satuan.

b. Nilai koefisien regresi sebesar 0.608 menunjukkan jika pengawasan meningkat, maka kinerja pegawai pada Kantor Dinas Perindustrian dan Perdagangan Provinsi Riau akan meningkat sebesar 0.608 satuan.

Berdasarkan hasil regresi sederhana diatas, maka dapat disimpulkan bahwa arah hubungan yang dimiliki variabel pengawasan kerja terhadap variabel kinerja pegawai memiliki arah hubungan yang positif, yaitu jika variabel bebas dalam hal ini pegawasan kerja tingkatkan atau diperbaiki, maka variabel terikat dalam hal ini kinerja akan mengalami peningkatan sebesar satuan.

\section{Uji_t}

Pembuktian Hipotesis ini dilakukan untuk melihat pengaruh variabel bebas secara parsial terhadap variabel terikatnya. Berikut adalah hasil output untuk uji_t menggunakan bantuan program SPSS, yaitu :

\section{Tabel 6 Uji_t}

\begin{tabular}{|c|c|c|c|c|c|c|}
\hline \multirow{2}{*}{\multicolumn{2}{|c|}{ Model }} & \multicolumn{2}{|c|}{$\begin{array}{l}\text { Unstandardized } \\
\text { Coefficients }\end{array}$} & \multirow{2}{*}{\begin{tabular}{|c|}
$\begin{array}{c}\text { Standardized } \\
\text { Coefficients }\end{array}$ \\
Beta \\
\end{tabular}} & \multirow[b]{2}{*}{$t$} & \multirow[b]{2}{*}{ Sig. } \\
\hline & & $\mathrm{B}$ & Std. Error & & & \\
\hline \multirow[t]{2}{*}{1} & (Constant) & 11.206 & 2.983 & & 3.757 & .000 \\
\hline & Pengawasan & .608 & .063 & .762 & 9.626 & .000 \\
\hline
\end{tabular}

Sumber, hasil SPSS 19

Dari tabel 6 diatas maka dapat dibuktikan kebenaran dari hipotesis yang penulis ajukan pada bab sebelumnya. Uji t ini dilakukan dengan membandingkan thitung atau dengan t-tabel pada signifikan $5 \%(\alpha=0,05)$. Untuk nilai t tabel diperoleh sebagai berikut : n-2 (baris), 1/2 $\alpha$ (kolom) maka diperoleh $69-2=67$ (baris) dan $1 / 2 \alpha$ $=0.025$ (kolom, sehingga nilai t_tabel diperoleh sebesar 1.99601. Berdasarkan output diatas diperoleh nilai t-hitung sebesar 9.626 sedangkan untuk nilai t_tabel diperoleh sebesar 2.0129, maka hal ini dapat dijelaskan bahwa nilai t_hitung (9.626) > dari t_tabel (1.99601), sehingga dapat disimpulkan Eko dan Bisnis (Riau Economics and Business Reviewe) Volume 10, Nomor 4, 27 Desember 2019 bahwa ada pengaruh yang signifikan pengawasan terhadap kinerja pegawai .

\section{Koefesien Determinasi}

Koefisien determinasi menunjukkan seberapa besar pengaruh variabel bebas terhadap variabel terikat. Berikut adalah hasil output koefesien determinasi.

Tabel 7 Koefesien Determinasi

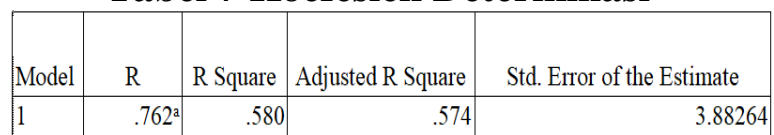

Sumber, hasil SPSS 19

Berdasarkan tabel 7 diatas, maka dapat diperoleh nilai $R \_s q u a r e ~ a t a u$ koefesien determinasi sebesar 0.580, yang memiliki arti besarnya pengaruh variabel pengawasan terhadap kinerja sebesar $58.0 \%$ sedangkan sisanya sebesar $42.0 \%$ menggambarkan variabel bebas lainnya yang tidak diamati dalam penelitian ini.

\section{SIMPULAN}

Berdasarkan hasil penelitian yang dilakukan peneliti, maka adapun kesimpulan dalam penelitian ini adalah :

1. Dari hasil deskripsi maka dapat disimpulkan bahwa untuk variabel kinerja memiliki nilai rata-rata sebesar 3.96 yang berarti Setuju. Sedangkan untuk variabel pengawasan kerja memiliki nilai rata-rata sebesar 3.89 yang berarti Setuju.

2. Dari hasil uji kualitas data diperoleh bahwa data sudah valid, reliabel, sehingga jawaban responden sudah layak untuk dilakukan penelitian lebih lanjut.

3. Dari hasil regresi linier sederhana diperoleh persamaan regresinya yaitu $Y=11.206+0.608 X$. Hal ini berarti memiliki arah hubungan yang positif antara variabel pengawasan kerja terhadap variabel kinerja.

Hasil uji hipotesis diperoleh bahwa variabel bebas dalam hal ini variabel kepuasan kerja berpengaruh signifikan terhadap variabel terikat dalam hal ini kinerja, hal tersebut dapat dilihat bahwa nilai t_hitung (9.626) > dari t_tabel

P.ISSN: 1410-7988 E.ISSN: 2614-123X 
(1.99601), sedangkan besarnya pengaruh variabel pengawasan kerja terhadap variabel kinerja pegawai sebesar $\mathbf{5 8 . 0 \%}$.

\section{DAFTAR RUJUKAN}

Abdurrahmat Fathoni, 2006, Manajemen Sumber Daya Manusia, Bandung : Rineka Cipta.

Amin Widjaja Tunggal, 1993,Manajemen Suatu Pengantar, Rineka Cipta, Jakarta

Andi Supangat, Drs, MSi, 2010. Statistika Dalam Kajian Deskriptif, Inferensi dan Nonparametrik, Kencana, Jakarta

Algifari, 1997. Analisis Statistik untuk Bisnis. Jakarta: Ghalia.

Basir Barthos, 2003, Manajemen Sumber Daya Manusia Suatu Pendekatan Makro, PT Bumi Aksara, Jakarta.

Dessler, G. 2009. Manajemen Sumber Daya Manusia. Jakarta : Index.

Anwar, 2015. Pengaruh Pengawasan Terhadap Kinerja Pegawai Basarnas Kota Pekanbaru. STIE, Pekanbaru.

Dwi Puspita Sari, 2011. Pengaruh Disiplin Dan Pengawasan Kerja Terhadap Kinerja Karyawan Pada Pt. Karyadeka Alam Lestari Semarang. UNNES, Semarang

Faustino. Cardoso Gomes. 2003, Manajemen Sumber Daya Manusia, Penerbit Andi, Yogyakarta.

Griffin, 2004. Manajemen, alih bahasa Gina Gania, Erlangga, Jakarta.

Hall T. Douglas. \& James Goodale G, 1986. Human Resources Management, Strategy, Design and Impelementation, Scott Foresman and Company, Glenview.

Hani Handoko, 2010, Manajemen Personalia \& Sumberdaya Manusia, Edisi kedua, BPFE UGM Yogyakarta.

Harahap, Sofyan, 2001. Sistem Pengawasan Manajemen, Penerbit Quantum, Jakarta.

Hasibuan, Malayu P. 2001. Manajemen : Dasar, Pengertian, dan Masalah, Bumi Aksara, Jakarta.

Mathis, R dan Jackson, W.2006. Human Resources Development (Track MBA series/terjemahan). Jakarta; Prestasi Pustaka.

Mario Ardi, 2015. Pengaruh Pengawasan Pimpinan Terhadap Kinerja Pegawai Pada Dinas Pendapatan Kabupaten Kuantan Singingi. STIE, Pekanbaru.

Simbolon, Maringan Masry, 2004. Dasardasar dan Administrasi Manajemen, Ghalia Indonesia, Jakarta.

Sofyandi Herman , 2008. Manajemen Sumber Daya Manusia, Graha Ilmu Jakarta

Sudjana. 1996. Metoda Statistika. Bandung: Tarsito.

Sule Ernie T. dan Saefullah Kurniawan. 2005. Pengantar Manajemen. Jakarta: Prenada Media.

Veithzal Rivai, 2005. Manajemen Sumber Daya Manusia Untuk Perusahaan dari Teori ke Praktik, PT Raja Grafindo Persada, Jakarta. 